\title{
Diarrheal Diseases in Low- and Middle-Income Countries: Incidence, Prevention and Management
}

\author{
Jill W. Ahs*, Wenjing Tao, Jenny Löfgren and Birger C. Forsberg \\ Division of Global Health (IHCAR), Department of Public Health Sciences, Karolinska Institutet, 17177 Stockholm, \\ Sweden
}

\begin{abstract}
Diarrheal diseases due to infection constitute a major burden of disease. Dehydration resulting from diarrhea can be fatal. It is the cause of approximately 1.8 million deaths every year. The vast majority of these deaths are of children under five years of age living in low- and middle- income countries. Interventions to prevent diarrhea include provision of safe water, hand washing, the use of sanitation facilities, exclusive breastfeeding of infants and rotavirus vaccination. Diagnosis is guided by symptoms into one of three categories: acute watery diarrhea, dysentery or bloody diarrhea, or persistent diarrhea of longer than 2 weeks in duration. Treatment of diarrhea in children includes oral rehydration with a pre-formulated solution or with fluids that can be prepared and administered in the home. Zinc supplementation is recommended. Only in certain circumstances are antibiotics advised and anti-motility agents are discouraged. The lives of many children could be saved with proper case management of diarrhea. With immediate and sustained actions to decrease both the incidence and mortality attributed to diarrhea, the burden of this prominent public health threat could be dramatically reduced.
\end{abstract}

Keywords: Infectious diarrhea, dehydration, developing countries, gastrointestinal diseases, gastroenteritis.

\section{INTRODUCTION}

Diarrheal diseases constitute a major burden of disease in the world, especially in low- and middle-income countries (LMIC). Of all medical conditions, diarrhea is the second leading cause of healthy time lost to illness (72.8 million DALYs) [1]. Dehydration resulting from diarrhea causes approximately 1.8 million deaths every year [1]. These illnesses are particularly dangerous for young children, who are more susceptible to dehydration and nutritional losses during an episode of acute diarrhea. Around $90 \%$ of all diarrhea-related deaths occur in children under five years of age living in LMIC [2].

Case estimates of diarrhea in both children and adults are staggering [3]. Globally, some 2-4 billion episodes of diarrhea occur every year [4] and this overwhelming level of morbidity has seen little decrease during the last four decades [3]. Currently, less than half of all young children with diarrhea receive appropriate treatment [5], and in some LMIC, the rates of appropriate case management are declining [6]. These issues are described in a recent joint report by UNICEF and WHO, accompanied by a strategy to reduce the burden of diarrheal diseases [7].

Many of the risk factors for contracting diarrheal illnesses are associated with poor socioeconomic conditions, such as lacking access to safe water and sanitation, poor hygiene practices and unsafe human waste disposal [8-10]. Low socioeconomic status can limit access to health care and education, and can affect diet, housing conditions and other

*Address correspondence to this author at the Division of Global Health (IHCAR), Department of Public Health Sciences, Karolinska Institutet, 171 77 Stockholm, Sweden; Tel: +46 (0)8 524833 57; Fax: +46 (0)8 3115 90; E-mail: jill.w.ahs@gmail.com factors that increase likeliness of exposure to infectious organisms or reduce resistance to infectious diseases. Children in households with lower socioeconomic status receive oral rehydration therapy (fluids taken by mouth to prevent or treat dehydration) less often than children in households with higher socioeconomic status [11].

In the following review, we will describe the pathology of diarrheal diseases, selected viral and bacterial organisms and the manner by which they cause diarrheal illness, and the prevention and treatment of diarrheal diseases. We offer a discussion of the illness, from the pathology at the cellular level to improvements at the societal level that could lead to a reduction in the global burden of infectious diarrheal diseases.

\section{MECHANISM OF DIARRHEA AND SUBSEQUENT DEHYDRATION}

Diarrhea can be described as the passing of loose or liquid stools. It is generally defined as three or more loose or watery stools within a 24-hour period [12], or a decrease in the consistency of the stool from that which is normal for the patient [13]. In LMIC, diarrhea is most often a symptom of gastrointestinal infection caused by bacteria, viruses or parasites. Commonly, these pathogens are transmitted via the fecal-oral route, where the pathogens are excreted from the intestinal tract of a person or animal carrying the illness and are ingested by another.

In the intestinal tract, the movement of fluids is guided principally by the active secretion of chloride ions across the epithelium. Absorption of fluids from the lumen is driven, for the most part, by the uptake of sodium in combination with digested nutrients when present, or coupled with chloride when fasting [14]. Diarrhea occurs when the absorption and secretion of ions and solute across the 
intestinal epithelium is disrupted, such that water moves into the lumen in an attempt to restore the appropriate ion concentrations. The vast surface area of the intestinal epithelium can allow rapid and grave changes to the concentration of circulating electrolytes [14].

Dehydration occurs when water and electrolytes are lost and not adequately replaced. In the early stages, there may be no clinical signs. As dehydration increases, symptoms may include thirst, restlessness or irritability, loss of skin turgor, sunken eyes, and a sunken fontanelle in infants [13]. A severely dehydrated patient may show lethargy, diminished consciousness, a decreased or complete lack of urine output, low blood pressure, a rapid pulse that may be hard to detect, and cool moist extremities that may appear cyanotic [13]. Without rehydration, the severely dehydrated patient's essential body functions may collapse, resulting in seizures, brain damage, or ultimately, death [15].

\section{ETIOLOGY}

Understanding the etiology of diarrhea is important for guiding the research and development of new preventive measures, diagnostic tools and treatments for diarrheal illnesses in LMIC. Case management, however, is guided by symptoms, as described in the section Syndromic Diagnosis of Diarrhea.

Numerous pathogens can cause diarrhea. In general, the same pathogens are responsible for infectious diarrhea worldwide, but their reported frequency may vary depending on the geographic location of the study or the population sampled. For example, enteric infections may differ according to the age or diet of the population, a rural setting versus an urban setting, community versus hospital setting, and also the season in which the study takes place. Furthermore, variations in reported frequency may reflect the diagnostic tools used, rather than the actual incidence of each pathogen.

An additional consideration when examining the etiology of enteric illness is that more than one pathogen may be implicated in cases of diarrhea, and in some circumstances, co-infections may be common [16-21]. Certain microbes, like rotavirus, Salmonella spp., Shigella spp., enteropathogenic Escherichia coli (EPEC), enteroaggregative E. coli (EAEC) and Vibrio cholerae seem to contribute greatly to mortality $[22,23]$. Some of the most life-threatening viral and bacterial pathogens affecting individuals in LMIC are described below.

\section{Rotavirus}

Rotavirus is thought to be the infectious agent most commonly causing severe diarrhea in young children [24$26]$. It is estimated that nearly every child (95\%) will have a rotavirus infection before reaching the age of five [25-27]. The illness caused by rotavirus is often severe [28, 29], is associated with concomitant fever and vomiting [30, 31], and is responsible for roughly $40 \%$ of all diarrhea-related hospitalizations worldwide $[24,25]$. This virus is the cause of more than half a million deaths every year [25, 32], and approximately $5 \%$ of all deaths of children under 5 years of age worldwide [33].
Rotavirus is transmitted primarily through the fecal-oral route, from contact with an infected person or a contaminated surface [27]. Improved sanitation is not sufficient to reduce the spread of this virus, as indicated by similar rates of incidence in developed and developing countries [34]. The pathogenic mechanism of rotavirus is to invade and destroy intestinal villi. The enterotoxin released inhibits the disaccharidases and glucose-stimulated $\mathrm{Na}+$ absorption of the microvilli-covered surface of the intestinal epithelium $[35,36]$. In children between three- and thirty-six months of age, the first rotavirus infection is generally the most severe [26], with subsequent infections being of decreasing severity. Thus, infection likely provides some protection for the host against severe future infections [37].

\section{Shigella}

The vast majority of infections by Shigella bacteria take place in LMIC (99\% of cases in 1999) [38]. Shigella can resist a low $\mathrm{pH}$, and the small number of organisms required to cause infection can be transmitted via contact with an infected person or a contaminated surface $[12,39]$.

Shigella can selectively invade enterocytes as well as M cells [40, 41], then multiply and spread inter- and intracellularly. The inflammation and ulceration caused by Shigella can result in febrile diarrhea or dysentery. The bacteria's secretion of Shiga toxin results in neurotoxic, cytotoxic and enterotoxic effects, blocking the intestine's absorption of electrolytes, glucose, and amino acids [42]. The immune response of the host and generation of cytokines contributes to the disease process [42], which finally results in necrosis of host cells [43].

\section{Vibrio Cholerae}

Vibrio cholerae is endemic in multiple locations, including Africa and Asia, and is a cause of large-scale outbreaks [44]. Untreated cases have a high case-fatality rate [45]. $V$. cholerae are easily destroyed by the gastric acid, and millions of organisms are required for symptomatic infection. Consequently, this microbe must first multiply in food or water in order to reach a sufficient number to cause infection [12].

While the infection causes no histological changes in the intestine, vast amounts of water and electrolytes are excreted. $V$. cholerae override the normal signaling pathways of the epithelium, activating chloride secretion while preventing sodium-hydrogen exchange. The consequent blockage of $\mathrm{NaCl}$ absorption results in the disruption of intestinal transport mechanisms and causes a characteristically massive loss of fluids $[14,46]$.

\section{Escherichia coli}

E. coli are a varied group of organisms including both pathogenic and harmless strains. The infectious types are grouped according to factors that characterize their pathogenic mechanism.

\section{Enterotoxigenic E. coli}

Enterotoxigenic E. coli (ETEC) is a common cause of diarrhea in infants and children in developing countries and the most common cause of traveler's diarrhea [47, 48]. The infectious dose required for ETEC infection is quite large 
[49], and the result is a non-inflammatory diarrhea similar to that of $V$. cholera, yet in most cases, less severely dehydrating [50].

The ETEC adhere to the enterocytes, colonize the small intestine, and proceed to secrete toxins. Many clinical isolates secrete just the heat-stable enterotoxin (ST), triggering diarrhea by binding to guanylate cyclase $\mathrm{C}$ and causing elevated levels of intracellular cGMP [51]. The heatlabile (LT) enterotoxin greatly resembles cholera toxin [52] as it acts on intestinal epithelia, activating adenylate cyclase by ADP ribosylation of Gs [53]. ETECs may secrete one or both types of toxin.

\section{Enteropathogenic E. coli}

Enteropathogenic E. coli (EPEC) is responsible for thousands of deaths every year, and on average, $5-10 \%$ of pediatric diarrheal episodes in the developing world, when diagnosis is made using molecular methods [54]. EPEC adhere to epithelial cells and activate cellular signaling, leading to intestinal secretion [55-57]. As the bacteria disrupt the microvilli-covered surface of the cell, the absorptive area is diminished (9). The usual EPEC infection is likely to be significantly longer in duration than other enteric infections $[58,59]$. When compared to cases of diarrhea caused by other pathogens, children suffering from an EPEC infection are more likely to develop persistent diarrhea, are more likely to fail to respond to ORS and are more likely to require hospitalization [60].

\section{Enteroaggregative E. coli}

Enteroaggregative E. coli (EAEC) is an emerging pathogen, and is increasingly recognized as a cause of acute and persistent diarrhea [61]. It can be found all over the world, in both adults and children. The greatest burden of EAEC is in developing areas, where it is associated with infectious diarrhea in young children and has a tendency to cause persistent illness [62]. EAEC infections most often cause watery diarrhea $[63,64]$ but, there is a suggested inflammatory component [65]. The illness is often indistinguishable from that caused by ETEC. EAEC has been implicated in outbreaks and it is a cause of traveler's diarrhea [61]. The bacteria adhere to the epithelial cells and a biofilm forms on the surface of the enterocyte, resulting from mucus produced by host and bacteria. Finally, toxins are released, eliciting intestinal secretion and an inflammatory response $[61,66]$.

\section{Salmonella}

Salmonella spp. can infect both humans and animals, and are a common type of food borne pathogen [67]. Nontyphoid Salmonella serovars cause as much as an estimated 1 billion cases of gastroenteritis in humans every year [68,69]. Salmonella undermine cellular signaling, membranetrafficking and pro-inflammatory responses [70]. Upon ingestion, Salmonella invade the intestinal mucosa by multiple mechanisms, including the invasion of $\mathrm{M}$ cells and being taken by dendritic cells, and they replicate intracellularly in non-phagocytic cells $[67,69]$. The pathogen can induce cell death in various types of host cells [67]. Salmonella-induced gastroenteritis can present with diarrhea and concurrent fever [68].
Typhoidal S. enterica serovars, mostly restricted to humans [69], are responsible for some 20 million cases of enteric fever worldwide every year [71]. While most Salmonella infections remain localized to the intestine and cause diarrhea, typhoid strains can survive in intestinal macrophages, disseminate to the liver and spleen and cause systemic infection [70]. Clinical indications of typhoid can include constipation in adults, hepatosplenomegaly and sustained high fever of up to 40c /104F [72].

\section{SECONDARY EFFECTS OF DIARRHEAL ILLNESS}

Enteric pathogens can cause dehydration and injury to the intestines by the processes described above. They can also result in damaging effects on other body systems. Numerous long-lasting physical complications can result from infectious diarrhea. For example, bacteremia can result from infection by Salmonella or Campylobacter, and hemolytic uremic syndrome (HUS) can follow infection by Shigella or enterohemorrhagic E. coli (a subset of Shiga toxin-producing E. coli or STEC) [73]. Guillain-Barré syndrome, a debilitating auto-immune disorder, can occur subsequent to infection by Campylobacter jejuni $[74,75]$. Reiter's syndrome, characterized by arthritis, urethritis, and conjunctivitis, may result from or accompany infection by Salmonella, Campylobacter, or Shigella [76].

Studies have documented long-term physical and cognitive deficits as a result of childhood diarrhea. Growth shortfalls have been found in children at the age of seven, who had suffered from diarrhea in early childhood [77]. Some particular enteric pathogens, such as EAEC and Cryptosporidium spp., can have negative effects on growth even when diarrhea is not evident [65, 78-80]. Diminished cognitive abilities have been observed in schoolchildren at 9 years of age who had suffered repeated episodes of diarrhea before the age of two [81-83]. As illustrated by these reports, the possible effects of infectious diarrhea include longlasting and permanent detriment, which can have immense impacts on people's lives and consequently on society.

\section{HOST SUSCEPTIBILITY TO INFECTIOUS DIARRHEA}

Humans are constantly exposed to potentially infectious organisms, and the bodies' defenses against infection are essential to survival. The ability to resist enteric infection can differ based on heritable factors, such as the genetics that determine the intestinal environment, as well as an individual's immune response when faced with infection [for a review see 84]. Two factors that can affect a host's susceptibility to diarrheal illness are malnourishment and infection with the human immunodeficiency virus (HIV).

\section{Malnutrition}

Malnutrition may influence the ability of the body to respond to infectious organisms. Risk for diarrheal illness due to ETEC, Entamoeba histolytica and Cryptosporidium is significantly higher in malnourished children [85]. Though the mechanism is a matter of continued research, one finding is that malnourished children produce lower amounts of IFNgamma and increased amounts of interleukin-5, both of which play an important part in immune defense [86]. Enteric infection in malnourished children is associated with increased occurrence of dehydration, fever, vomiting, prolonged illness, hospitalization, and in the long-term, 
growth and developmental shortfalls [87]. As much as $61 \%$ of childhood deaths due to diarrheal illness may be attributed to underlying malnutrition $[88,89]$.

\section{Diarrhea in HIV-Positive Individuals}

Geographically, there is an overlap of areas with a large burden of diarrheal illness and those with a large proportion of HIV cases. Thus, HIV-positive status is an important consideration in the discussion of diarrhea in LMIC. Individuals who are HIV-positive are particularly susceptible to common pathogens, opportunistic agents and malnutrition [90-92]. Some enteric pathogens occur more frequently in HIV-positive individuals than in the general population, including Campylobacter [93, 94], Cryptosporidium [95] and Shigella [96]. Many enteric illnesses can be more severe in those who are infected with HIV, including non-typhoid salmonellosis [97-100], shigellosis and cryptosporidiosis [101].

\section{REDUCING INFECTIOUS DIARRHEAL ILLNESSES}

As diarrheal pathogens are commonly transmitted in water, in food, or by personal contact with the carrier or a contaminated surface, critical places where transmission of diarrheal disease may be halted are on hands, in water and in foods. In addition to these actions to prevent exposure to diarrheal illness, the administration of vaccines and provision of adequate nutrition is likely to enhance an individual's ability to resist infection when exposed.

\section{Improved Water Quality}

Nearly one billion people in this world are currently relying on unimproved water sources for drinking and for other domestic activities. These sources can include unprotected wells, ponds and rivers. Even where water sources are considered to be improved, the water may not meet the microbiological standards set by WHO [102].

The improvement of water quality at the source can include measures to protect the source with a physical barrier to prevent contamination by humans or animals. Water quality improvements can also serve to prevent contamination by human and animal waste from ground runoff or leaching sewerage.

Household water treatment is more effective at preventing diarrhea than interventions at the water source $[103,104]$. Household treatment, or point-of-use water treatment, can be performed by heat or ultraviolet radiation, chemical treatment (e.g., chlorine tablets), physical removal (e.g., filtering or sedimentation) or a combination of these approaches, immediately prior to consumption. However, some of these practices do not remove all infectious agents. The safe handling and safe storage of water should be practiced concomitantly with water quality improvements, to prevent contamination by hands, animals, utensils or flies during the transport or storage of water.

\section{Improved Quantity and Ease of Access to Water}

The benefits of improving access to water are undisputed as a measure to reduce diarrheal illness. Especially in rural areas of LMIC, household members can spend hours each day to transport water for household use. While provision of improved water supply does not necessarily result in a change in water usage, it is proposed that improved access to water can facilitate better hygiene practices [105], and more hand washing in particular [106]. Quantity of water and convenience of the source is more important than quality of water for reducing diarrheal illnesses [105].

\section{Improved Hand Hygiene Practices}

Hand washing after defecation and after cleaning up a child's feces is a particularly important measure at the individual level to reduce spread of pathogens [107, 108]. Hand washing with soap is most effective, reducing diarrheal illness by $42-47 \%$ [109]. When soap is not available, a local material like ashes can be substituted.

\section{Sanitation and Flies}

The use of facilities for sanitation is an important measure to reduce the spread of diarrheal illness, second only to hand washing. Currently, an overwhelming 1.2 billion people, or $18 \%$ of the world population, practice open defecation. This action, practiced by nearly half of the population in Southern Asia and more than $25 \%$ of people living in SSA, puts an individual's own health at risk, as well as the health of family, neighbors, and the entire community [110]. Open defecation in fields used for farming can directly contaminate food supplies and enter water supplies. Additionally, human and animal feces in fields and in the environment provide houseflies with a place to breed and to pick up pathogens. The common housefly is a known source of diarrheal illness, as they can carry and spread bacterial enteropathogens $[111,112]$. Therefore, the safe disposal of feces can eliminate direct contamination of farmed crops, indirect contamination of water supplies, a breeding place for flies and a source of the fecal pathogens that flies can spread.

\section{Breastfeeding and Hygienic Food Preparation}

For infants, exclusive breastfeeding during the first sixmonths of life can reduce the possibility for ingestion of enteric bacteria from contaminated water, food, formula, and bottles. Breastfed infants under 6 months of age are 6.1 times less likely to die of diarrhea than infants who are not breastfed [113]. The immunological properties of breast milk protect the infant from infection, especially diarrhea [13]. The anti-infective components of breast milk include secretory IgA, lactoferrin, and immune cells that produce lysozyme, which destroy bacteria, and cells that produce interferon, which has antiviral properties [114]. A child six months of age or older and adults can benefit from eating only food that is prepared and stored in a hygienic manner, thus preventing the introduction of pathogens into the diet.

\section{Vaccines}

Immunizations to protect against enteric illness are available in increasing numbers and geographic locations, as documented and supported by international collaborations, such as GAVI Alliance, the Global Alliance for Vaccines and Immunizations. Currently, vaccines are available for preventing diarrheal illness caused by rotavirus, $V$. cholerae 01, and Salmonella Typhi. Measles, which has a complex but positive association with childhood diarrhea mortality, is achieving increased vaccine coverage [115]. Rotavirus vaccination of infants is now recommended by the World 
Health Organization for inclusion in all national immunization programs, and is strongly recommended where diarrhea mortality exceeds $10 \%$ of all under-five deaths $[116,117]$. Oral cholera vaccines are available, but not deployed widely in endemic areas. They have been used successfully in epidemics $[118,119]$, though many factors complicate the potential for successful use in such settings [120]. Vaccines for Salmonella Typhi are available and used by travelers, and perhaps future vaccines will impart longerlasting immunity [121]. Though a priority, there is no licensed vaccine targeting Shigella [122]. A vaccine that is effective against ETEC in adult travelers is licensed in few countries, and the development of a new ETEC vaccine candidate is sought [123]. Other enteropathogenic vaccines are in development, for example Campylobacter jejuni [124] and Cryptosporidium parvum [125], yet many challenges remain in vaccine development.

\section{SYNDROMIC DIAGNOSIS OF DIARRHEA}

In order to guide optimal case management, and for the purposes of epidemiological tracking, a diarrheal episode is often diagnosed according to symptoms into one of the following three categories: acute watery diarrhea, dysentery or bloody diarrhea, or persistent diarrhea. Each of these categories has unique considerations that direct the clinician to provide appropriate care.

\section{Acute Watery Diarrhea}

The majority of episodes of diarrhea would be classified as acute watery diarrhea. Secretory organisms, in general, lead to diarrheal symptoms described as acute watery diarrhea. Agents causing this noninflammatory type of enteric illness often produce enterotoxins, as in the case of $V$. cholerae or ETEC. Alternatively, they may disrupt the normal absorptive or secretory processes of the enterocyte, as in the case of viruses or Giardia, without destroying the mucosa or causing acute inflammation. Though typically mild, this type of illness can rapidly lead to dehydration. In such cases, the infection may be due to rotavirus, ETEC or $V$. cholerae [12]. Cases of watery diarrhea lasting 7 days or longer can have a resulting nutritional penalty [83].

\section{Dysentery or Bloody Diarrhea}

Clinically, bloody diarrhea is the term used to describe stools that may either visibly contain blood or that contain blood detectable by microscopy. Dysentery describes characteristically small-volume bloody or mucoid stools accompanied by abdominal cramping and tenesmus. Often, however, these terms are used interchangeably and fever is a concomitant symptom of both. Dysentery or bloody diarrhea is the result of inflammatory or invasive organisms. In the case of invasive organisms, fecal leukocytes or lactoferrin are usually present [126]. Pathogens causing dysentery or bloody diarrhea may destroy cells in the gut or invade the mucosa and result in inflammation or ulceration. Inflammatory organisms include cytotoxin-producing noninvasive bacteria, such as EAEC, and invasive pathogens, like Shigella, Salmonella, Campylobacter, and amoeba. Fever can be the result of an enterotoxin, or indication of colonic tissue damage by an invasive organism [126].

\section{Persistent Diarrhea}

The distinguishing characteristic of persistent diarrhea is solely the duration of illness; persistent diarrhea lasts longer than 14 days. The causes of persistent diarrhea include multiple successive gastrointestinal infections or an infection that has not been resolved. Though persistent diarrhea can be the result of any one of many different enteric pathogens, the most important are Giardia, Cryptosporidium spp., EAEC and EPEC [56, 87]. When persistent diarrhea is the result of bloody diarrhea, as is frequently the case, the associated risk of death is 10 times greater than in cases of bloody diarrhea that are less than two weeks in duration [12]. In the case of a child, the risk of death from persistent diarrhea can increase if he or she was malnourished prior to contracting the illness or suffered other systemic infections [87].

\section{CASE MANAGEMENT OF INFECTIOUS DIARRHEA}

Diarrhea case management can be divided into assessment, treatment and follow up. The assessment aims to classify the patient's level of dehydration and determine the type of diarrheal illness (acute, dysentery or persistent diarrhea). Treatment may include oral rehydration, zinc treatment, antibiotics for selected cases, intravenous fluids for the most severe cases and nutritional rehabilitation in certain cases. Follow-up may range from hourly observations of a severely dehydrated patient, to reassessment after 4 hours for a patient with some dehydration. A patient may require follow-up after a number of days of treatment if they presented with persistent or bloody diarrhea.

\section{Assessment and Correction of Dehydration}

Dehydration is the major cause of suffering and the leading risk for death in cases of diarrhea. Immediately upon presentation, a physical assessment is performed to grade the patient's degree of dehydration into one of following categories: no dehydration, some dehydration and severe dehydration. This clinical examination should include an evaluation of the patient's general condition, his or her desire to drink or not (including not being able to drink because of drowsiness), history of urinary output, assessment of skin elasticity, and observation to determine if mucus membranes appear dry, and if eyes appear sunken. In elderly patients, dryness of the tongue is a useful indicator of dehydration status $[127,128]$. When the status for level of dehydration has been determined, the appropriate rehydration treatment plan is initiated (see Fig. 1).

When a patient presents without signs of dehydration, the main principle of treatment is that they should be given plenty of appropriate fluids to correct fluid losses and prevent dehydration. These fluids can include liquids that may be available at home that are rich in nutrients and salts, like soups and salted rice water, or oral rehydration salts (ORS) may be administered. The latter is a fluid prepared by mixing the contents of a pre-formulated package containing glucose, sodium and a base like sodium tricitrate in a determined amount of water. More recently, a hypo-osmolar ORS has been introduced and it is now recommended by the World Health Organization as the treatment of choice for dehydration in children [129]. The primary function of ORS is to correct dehydration and metabolic acidosis. 


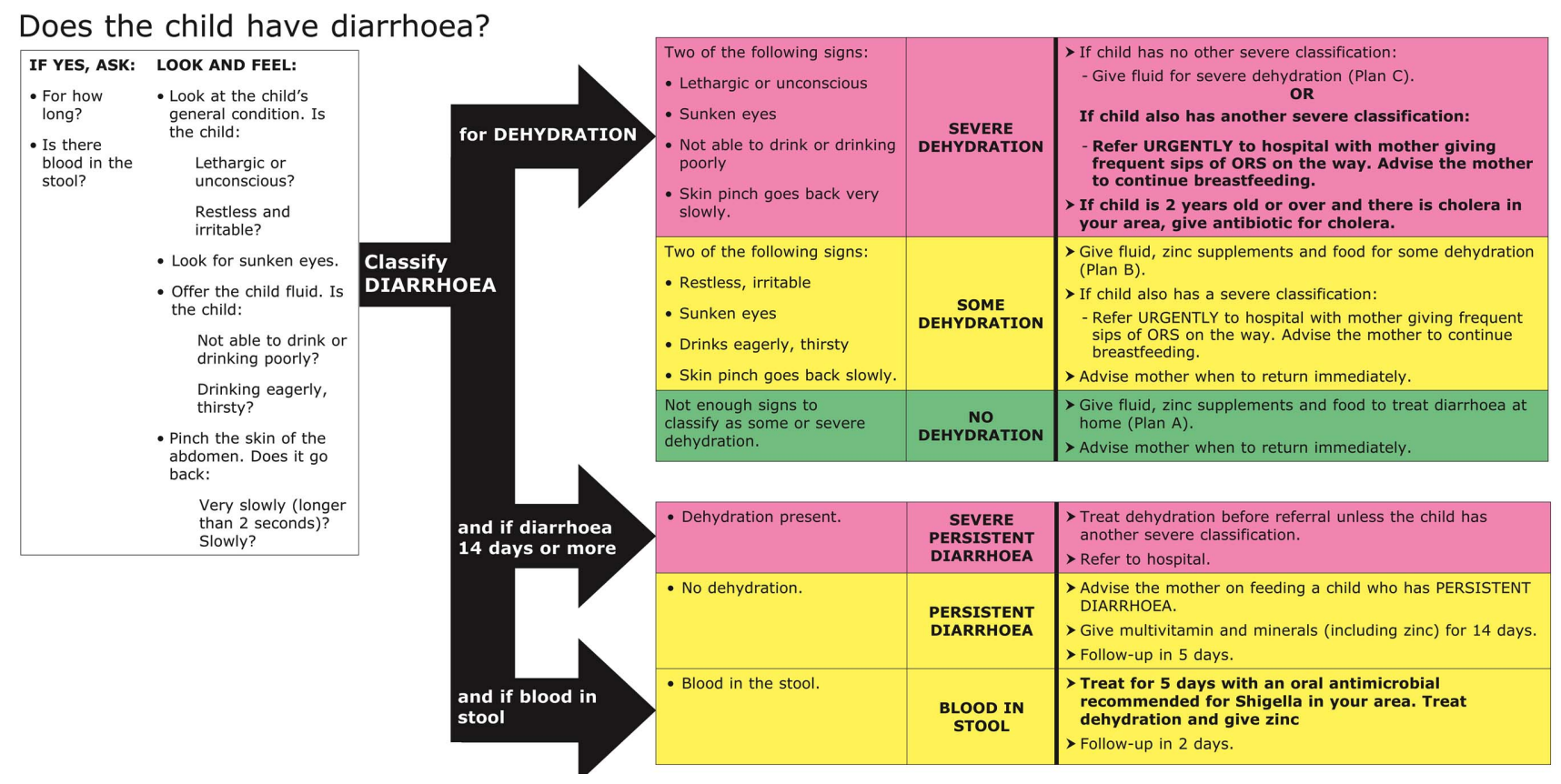

World Health Organization Disease Control Programme Diarrhoea treatment guidelines including new recommendations for the use of ORS and zinc supplementation for clinic-based healthcare workers. Geneva: World Health Organization, 2005.

Fig. (1). World Health Organization Diarrhoea Treatment Chart.

Children who are breastfed should continue feedings throughout the diarrhea episode. For any patient with diarrhea, adequate food intake should be maintained during and following the episode.

For the patient who displays signs of some dehydration, oral rehydration solutions should be administered in a health facility. During the first 4 four hours, a child should receive an amount of ORS roughly equal to $75 \mathrm{ml}$ per kilogram of weight, but adjusted for dehydration status, amount of stools passed and other considerations [see 13]. For a small child, ORS may be administered at a rate of roughly one teaspoonful every one-two minutes, whereas older children or adults may sip from a cup. In initial stages of rehydration, an adult may require up to $750 \mathrm{ml}$ of ORS per hour. If a patient vomits, ORS administration may resume after 10 minutes, but at a slower pace. The patient should be monitored for signs of over-hydration, such as puffy eyelids. If, at any time, the patient shows signs of severe dehydration, the treatment plan should be switched immediately to treat severe dehydration.

Patients that are severely dehydrated should be put on IV fluids, like Ringer's lactate, for 4 hours. Patients with some dehydration and those with severe dehydration should be reassessed after 4 hours to determine their dehydration status and then treated accordingly. Guidelines for treatment of dehydration are summarized in Fig. (1), while details may be ascertained elsewhere [13].

\section{Malnutrition}

A patient with diarrhea who is suffering from severe malnutrition (marasmus or kwashiorkor) is at risk of not only dehydration, but also severe systemic infection, heart failure and vitamin and mineral deficiency [13]. The rehydration of a severely malnourished patient with diarrhea should take place immediately and in a hospital. In a case of severe malnutrition, it may be difficult to differentiate the signs of some dehydration from those indicating severe dehydration, and the signs of severe dehydration could instead be those of septic shock. A malnourished patient should be rehydrated orally at a slow rate, with hypo-osmolar ORS.

\section{Zinc}

The WHO and UNICEF recommend that all children under 5 with diarrhea receive $10-20 \mathrm{mg}$ of zinc each day for 10-14 days [130]. The therapeutic effect of zinc in diarrhea was recognized more than a decade ago [131, 132]. Since then, several clinical trials and meta-analyses have shown benefits of zinc supplementation in childhood diarrhea [133138]. A short course supplementation with zinc reduces the severity and duration of both acute and persistent diarrhea [135]. It also acts protectively on the recurrence of diarrhea in the next 2-3 months [134]. In addition, trials that have evaluated the effect of a long-term daily or weekly supplementation with zinc have indicated a decrease in diarrhea morbidity among children $[134,136]$.

Zinc deficiencies are common in all parts of the world, particularly among children in low-income countries, mainly due to diet [139]. Zinc plays an essential role in metabolism, cellular growth and immunity. It is believed to affect the course of diarrhea through improving the absorption of water and electrolytes in the gut [140], regenerating the intestinal epithelium [141], increasing the levels of enterocyte brushborder enzymes [142, 143] and enhancing immune response for the clearance of pathogens [144]. However, the mechanisms through which zinc shows positive effects on diarrheal illness are yet to be clarified. 


\section{Antibiotics}

Antibiotics are only recommended for treating dysentery, cholera, and for certain cases of persistent diarrhea in children. For other instances of acute watery diarrhea, antibiotics do not have an important role in treatment [145, 146]. In dysentery caused by Shigella, treatment with appropriate antibiotics shortens the duration of the symptoms, including fever, diarrhea and dysentery, and reduces the duration of time that the host excretes the pathogen [147]. The current first choice of antibiotics recommended by the World Health Organization for treating shigellosis is ciprofloxacin. Alternatives that may be used include pivmecillinam for children or adults, or ceftriaxone in children [13]. Sulfonamides, ampicillin, trimethoprimsulfamethoxazole, and nalidixic acid used to be first-line therapies. Gradually, Shigella has become resistant to each of these antibiotics, and currently, increasing resistance to ciprofloxacin has been documented [148-152]. All patients who present with dysentery should be treated for shigellosis [153]. An exception to this would be if there is reason to suspect STEC. Antibiotic use in a case of enterohemorrhagic E. coli (EHEC) O157:H7 may place the patient at greater risk of HUS [154, 155] and could increase the amount of toxin produced by strains of STEC bacteria [156].

Antibiotics should be given in cases of cholera, as they significantly reduce the stool output [157]. The preferred antibiotics are doxycycline for adults, or tetracycline for treating children or adults; erythromycin may be used as an alternative [13]. In cases of non-typhoidal Salmonella, patients have shown prolonged shedding of the pathogen when treated with antibiotics, however patients at risk for disseminated disease, such as the immunosuppressed, should be treated [158].

For other infectious causes of diarrhea, antibiotics are not generally recommended [146, 159]. Clinically, it is not possible to distinguish pathogens that will respond to antibiotics from those that will not respond. Antibiotics add to the cost of treatment, put the patient at risk for adverse events, and can encourage development of resistant bacteria [13].

\section{Antimotility Agents}

For treatment of diarrhea in children, antimotility agents should always be avoided. Such drugs have not been shown to be effective and may have serious side-effects. Antimotility agents can also prove dangerous for adults in some cases, and their use is contraindicated for the treatment of bloody diarrhea and suspected or confirmed STEC [160].

\section{Management of Persistent Diarrhea}

Persistent diarrhea is a condition of concern in low- and middle-income countries. Factors associated with persistent diarrhea include malnutrition, micronutrient deficiencies and immunodeficiency [161]. Injury to the mucosa of the small intestine [162-164] and ineffective intestinal repair [161, 165] may be factors closely related to the pathogenesis of persistent diarrhea. In non-bloody persistent diarrhea in children, there is limited evidence to support use of antibiotics, especially in cases with unknown or non-specific etiology [166]. Children with persistent diarrhea need general treatment for diarrhea, special attention and supervision and often, nutritional rehabilitation.

\section{FUTURE DEVELOPMENTS IN THE DIAGNOSIS AND TREATMENT OF INFECTIOUS DIARRHEA}

As the burden of diarrheal illness remains high, we must continue to implement interventions that have been proven effective, but also encourage innovative new solutions that will allow for reductions in both the morbidity and the mortality attributed to diarrheal diseases. Many improvements have been made to allow for water and sanitation interventions to be more affordable and/ or sustainable. In addition, new technologies in medicine can improve diarrhea-related diagnoses and treatment.

\section{New Diagnostics for Infectious Diarrhea}

The advancement of molecular diagnostic tools now enables identification of pathogens that may have previously gone undetected [167], and can be used to determine the prevalence and molecular characteristics of pathogens. This could allow for improvements in case management and epidemiological tracking, and could identify the anthroponotic spread of infectious agents [168]. Such tools may also prove valuable for determining the potential effectiveness of certain interventions, such as vaccines [169, 170].

Tools that measure inflammation and mucosal destruction could allow better identification of severe illness and indicate those who may be in danger of long-term nutritional consequences of enteric infection. With wider availability of fecal lactoferrin tests, inflammation resulting from invasive enteropathogens could be diagnosed more often [171]. The consequences of enteric infection could also be measured by tests of intestinal permeability. Increased availability of tests to measure the lactulose/mannitol ratio, indicating damage to the epithelium, could identify children who have suffered intestinal damage from recurrent illness and who may benefit from further nutrition interventions [163].

\section{New Therapeutics to Treat Diarrhea}

At present, there are a number of prospective chemotherapies in development to treat diarrheal diseases. One example is the potential for recently discovered blockers of the cystic fibrosis transmembrane conductance regulator (CFTR) to be utilized in the development of treatments for diarrheal symptoms, including those of cholera infection [172]. Drugs that act as Cl- channel blockers may be effective to treat acute diarrhea [173].

Additionally, there have been many efforts to improve ORS. The primary function of ORS is to correct dehydration and metabolic acidosis. It does not act to reduce stool output. An idea to improve ORS is the addition of "resistant starch" to the newer hypo-osmolar ORS formula. This added starch resists breakdown by the digestive enzyme amylase. This starch can then allow for the increased production of shortchain fatty acids, the major anion in stool. Studies indicate that this product can decrease both stool output and the duration of diarrhea in adults with cholera [174], and in children with non-cholera diarrhea [175]. 


\section{CONCLUSIONS}

In low-and middle-income countries, diarrheal diseases continue to be an overwhelming problem. The estimated number of cases of diarrhea every year is staggering and does not seem to be declining. For children under five years of age, diarrhea is one of the leading causes of death. With correct treatment, the overwhelming majority of deaths in children from these diseases can be avoided. Current trends, however, indicate that case management of childhood diarrhea is not improving.

People living in poverty are at increased risk of diarrheal illness. The fact that children die today from diarrheal disorders is a sign of inequity in distribution of resources in the world. Medical staff is scarce and access to health services is a great challenge for many living in low- and middle-income countries.

However, interventions to prevent and treat diarrhea can be effective. Programs can promote healthful behaviors and improve access to water and sanitation. Caregivers can be trained to recognize symptoms of dehydration, to provide appropriate treatment, and to identify when outside help should be sought.

The lives of many children could be saved by promoting the use of simple treatments like oral rehydration therapy to the public through health services, community health workers and media. And, advancements in medicine, public health, and technology may allow new interventions to play a role in reducing the global burden of diarrheal illnesses. But, without immediate and sustained actions to reduce both the incidence and mortality due to diarrhea, these illnesses will continue to be a prominent threat to public health in low- and middle-income countries.

\section{CONFLICT OF INTEREST}

The authors declare no conflict of interest.

\section{REFERENCES}

[1] World Health Organization. The global burden of disease, 2004 update. Geneva, World Health Organ 2008.

[2] Kallander K. Infektionstermometern - en rapport om infektionssjukdomarnas inverkan på hälsoläget i världen. Boken om smittsamma sjukdomar. Stockholm: Världsinfektionsfonden 2007.

[3] Kosek M, Bern C, Guerrant RL. The global burden of diarrhoeal disease, as estimated from studies published between 1992 and 2000. Bull World Health Organ 2003; 81(3): 197-204.

[4] Farthing MJ. Diarrhoea- a significant worldwide problem. Int J Antimicrob Agents 2000; 14(1): 65-9.

[5] Forsberg BC, Petzold MG, Tomson G, Allebeck P. Diarrhoea case management in low- and middle-income countries-an unfinished agenda. Bull World Health Organ 2007; 85(1): 42-8.

[6] Ram PK, Choi M, Blum LS, Wamae AW, Mintz ED, Bartlett AV. Declines in case management of diarrhoea among children less than five years old. Bull World Health Organ 2008; 86(3): E-F.

[7] Wardlaw T, Salama P, Brocklehurst C, Chopra M, Mason E. Diarrhoea: why children are still dying and what can be done. Lancet 2010; 375(9718): 870-2

[8] Daniels DL, Cousens SN, Makoae LN, Feachem RG. A casecontrol study of the impact of improved sanitation on diarrhoea morbidity in Lesotho. Bull World Health Organ 1990; 68(4): 45563.

[9] Manun'ebo MN, Haggerty PA, Kalengaie M, Ashworth A, Kirkwood BR. Influence of demographic, socioeconomic and environmental variables on childhood diarrhoea in a rural area of Zaire. J Trop Med Hyg 1994; 97(1): 31-8.
[10] Graf J, Meierhofer R, Wegelin M, Mosler HJ. Water disinfection and hygiene behaviour in an urban slum in Kenya: impact on childhood diarrhoea and influence of beliefs. Int J Environ Health Res 2008; 18(5): 335-55.

[11] Forsberg BC, Gwatkin D, Tomson G, Allebeck P, Petzold MG. Socioeconomic Inequalities in the Prevalence and Management of Childhood Diarrhoea: Potential Health Gains to be Achieved. Open Infect Dis J 2009; 3: 44-9.

[12] Keusch GT, Fontaine O, Bhargava A, et al. Diarrheal Diseases. In Jamison D, Measham R, Claeson M, editors. Disease Control Priorities in Developing Countries, $2^{\text {nd }}$ ed. Washington: World Bank 2006.

[13] World Health Organization. Department of Child and Adolescent Health and Development. The treatment of diarrhoea: a manual for physicians and other senior health workers. 4th rev. ed. Geneva: World Health Organ 2005.

[14] Barrett KE. New ways of thinking about (and teaching about) intestinal epithelial function. Adv Physiol Educ 2008; 32(1): 25-34.

[15] Merson M, Black R, Mills A. International Public Health: Diseases, Programs, Systems and Polices. $2^{\text {nd }}$ ed. Boston: Jones and Bartlett Publishers 2006

[16] Al-Gallas N, Bahri O, Bouratbeen A, Ben Haasen A, Ben Aissa R. Etiology of acute diarrhea in children and adults in Tunis, Tunisia, with emphasis on diarrheagenic Escherichia coli: prevalence, phenotyping, and molecular epidemiology. Am J Trop Med Hyg 2007; 77(3): 571-82.

[17] Baqui AH, Black RE, Sack RB, Chowdhury HR, Yunus M, Siddique AK. Malnutrition, cell-mediated immune deficiency, and diarrhea- a community-based longitudinal study in rural Bangladeshi children. Am J Epidemiol 1993; 137(3): 355-65.

[18] Black RE. Epidemiology of diarrhoeal disease: implications for control by vaccines. Vaccine 1993; 11(2): 100-6.

[19] Albert MJ, Faruque AS, Faruque SM, Sack RB, Mahalanabis D. Case-control study of enteropathogens associated with childhood diarrhea in Dhaka, Bangladesh. J Clin Microbiol 1999; 37(11): 3458-64.

[20] Qadri F, Das SK, Faruque AS, et al. Prevalence of toxin types and colonization factors in enterotoxigenic Escherichia coli isolated during a 2-year period from diarrheal patients in Bangladesh. J Clin Microbiol 2000; 38(1): 27-31.

[21] Rao MR, Abu-Elyazeed R, Savarino SJ, et al. High disease burden of diarrhea due to enterotoxigenic Escherichia coli among rural Egyptian infants and young children. J Clin Microbiol 2003; 41(10): 4862-4.

[22] Petri WA, Jr., Miller M, Binder HJ, Levine MM, Dillingham R, Guerrant RL. Enteric infections, diarrhea, and their impact on function and development. J Clin Invest 2008; 118(4): 1277-90.

[23] Lanata CF, Mendoza W, Black RE. Improving diarrhoea estimates. Geneva- World Health Organ 2002.

[24] Centers for Disease Control and Prevention (CDC). Rotavirus surveillance-worldwide, 2001-2008. MMWR Morb Mortal Wkly Rep 2008; 57(46): 1255-7.

[25] Parashar UD, Gibson CJ, Bresse JS, Glass RI. Rotavirus and severe childhood diarrhea. Emerg Infect Dis 2006; 12: 304-6.

[26] Parashar UD, Alexander JP, Glass RI. Prevention of rotavirus gastroenteritis among infants and children. Recommendations of the Advisory Committee on Immunization Practices (ACIP). MMWR Recomm Rep 2006; 55(RR-12): 1-13.

[27] Glass RI, Parashar UD, Bresee JS, et al. Rotavirus vaccines: current prospects and future challenges. Lancet 2006; 368(9532): 323-32.

[28] Albano F, Bruzzese E, Bella A, et al. Rotavirus and not age determines gastroenteritis severity in children: a hospital-based study. Eur J Pediatr 2007; 166(3): 241-7.

[29] Nelson EA, Bresee JS, Parashar UD, Widdowson MA, Glass RI. Rotavirus epidemiology: the Asian Rotavirus Surveillance Network. Vaccine 2008; 26(26): 3192-6.

[30] Coffin SE, Elser J, Marchant C, et al. Impact of acute rotavirus gastroenteritis on pediatric outpatient practices in the United States. Pediatr Infect Dis J 2006; 25(7): 584-9.

[31] Staat MA, Azimi PH, Berke T, et al. Clinical presentations of rotavirus infection among hospitalized children. Pediatr Infect Dis J 2002; 21(3): 221-7.

[32] Parashar UD, Hummelman EG, Bresee JS, Miller MA, Glass RI. Global illness and deaths caused by rotavirus disease in children. Emerg Infect Dis 2003; 9(5): 565-72. 
[33] Dennehy PH. Rotavirus vaccines: an overview. Clin Microbiol Rev 2008; 21(1): 198-208.

[34] Centers for Disease Control and Prevention. Epidemiology and Prevention of Vaccine-Preventable Diseases. In: Atkinson W, Wolfe S, Hamborsky J, McIntyre L, Eds. $11^{\text {th }}$ ed. Washington DC: Public Health Foundation 2009.

[35] Ball JM, Mitchell DM, Gibbons TF, Parr RD. Rotavirus NSP4: a multifunctional viral enterotoxin. Viral Immunol 2005; 18(1): 27 40 .

[36] Beau I, Cotte-Laffitte J, Geniteau-Legendre M, Estes MK, Servin AL. An NSP4-dependant mechanism by which rotavirus impairs lactase enzymatic activity in brush border of human enterocyte-like Caco-2 cells. Cell Microbiol 2007; 9(9): 2254-66.

[37] Velazquez FR. Protective effects of natural rotavirus infection. Pediatr Infect Dis J 2009; 28(3 Suppl): S54-6.

[38] Kotloff KL, Winickoff JP, Ivanoff B, et al. Global burden of Shigella infections: implications for vaccine development and implementation of control strategies. Bull World Health Organ 1999; 77(8): 651-66.

[39] DuPont HL, Levine MM, Hornick RB, Formal SB. Inoculum size in shigellosis and implications for expected mode of transmission. $\mathbf{J}$ Infect Dis 1989; 159(6): 1126-8.

[40] Sansonetti PJ. Genetic and molecular basis of epithelial cell invasion by Shigella species. Rev Infect Dis 1991; 13(Suppl 4): S285-92.

[41] Sansonetti PJ, Phalipon A. M cells as ports of entry for enteroinvasive pathogens: mechanisms of interaction, consequences for the disease process. Semin Immunol 1999; 11(3): 193-203.

[42] Niyogi SK. Shigellosis. J Microbiol 2005; 43(2): 133-43.

[43] Zychlinsky A, Prevost MC, Sansonetti PJ. Shigella flexneri induces apoptosis in infected macrophages. Nature 1992; 358(6382): 167-9.

[44] WHO. Cholera, 2008. Weekly Epidemiological Record 2009; 84: 309-24.

[45] Mahalanabis D, Choudhuri AB, Bagchi NG, Bhattacharya AK, Simpson TW. Oral fluid therapy of cholera among Bangladesh refugees. Johns Hopkins Med J 1973; 132(4): 197-205.

[46] Field M. Mechanisms of action of cholera and Escherichia coli enterotoxins. Am J Clin Nutr 1979; 32(1): 189-96.

[47] Ericsson CD. Travellers' diarrhoea. Int J Antimicrob Agents 2003; 21(2): 116-24.

[48] DuPont HL. Systematic review: the epidemiology and clinical features of travellers' diarrhoea. Aliment Pharmacol Ther 2009; 30(3): 187-96

[49] Navaneethan U, Giannella RA. Mechanisms of infectious diarrhea. Nat Clin Pract Gastroenterol Hepatol 2008; 5(11): 637-47.

[50] Khan MU, Eeckels R, Alam AN, Rahman N. Cholera, rotavirus and ETEC diarrhoea: some clinico-epidemiological features. Trans R Soc Trop Med Hyg 1988; 82(3): 485-8

[51] Wolf MK. Occurrence, distribution, and associations of $\mathrm{O}$ and $\mathrm{H}$ serogroups, colonization factor antigens, and toxins of enterotoxigenic Escherichia coli. Clin Microbiol Rev 1997; 10(4): 569-84.

[52] Qadri F, Svennerholm AM, Faruque AS, Sack RB. Enterotoxigenic Escherichia coli in developing countries: epidemiology, microbiology, clinical features, treatment, and prevention. Clin Microbiol Rev 2005; 18(3): 465-83.

[53] Moss J, Richardson SH. Activation of adenylate cyclase by heatlabile Escherichia coli enterotoxin. Evidence for ADPribosyltransferase activity similar to that of choleragen. J Clin Invest 1978; 62(2): 281-5.

[54] Ochoa TJ, Barletta F, Contreras C, Mercado E. New insights into the epidemiology of enteropathogenic Escherichia coli infection. Trans R Soc Trop Med Hyg 2008; 102(9): 852-6.

[55] Chen HD, Frankel G. Enteropathogenic Escherichia coli: unravelling pathogenesis. FEMS Microbiol Rev 2005; 29(1): 8398.

[56] Pawlowski SW, Warren CA, Guerrant R. Diagnosis and treatment of acute or persistent diarrhea. Gastroenterology 2009; 136(6): 1874-86.
[57] Donnenberg MS, Kaper JB. Enteropathogenic Escherichia coli. Infect Immun 1992; 60(10): 3953-61.

[58] Nguyen RN, Taylor LS, Tauschek M, Robins-Browne RM. Atypical enteropathogenic Escherichia coli infection and prolonged diarrhea in children. Emerg Infect Dis 2006; 12(4): 597-603.

[59] Afset JE, Bevanger L, Romundstad P, Bergh K. Association of atypical enteropathogenic Escherichia coli (EPEC) with prolonged diarrhoea. J Med Microbiol 2004; 53(Pt 11): 1137-44.

[60] Fagundes-Neto U, Scaletsky IC. The gut at war: the consequences of enteropathogenic Escherichia coli infection as a factor of diarrhea and malnutrition. Sao Paulo Med J 2000; 118(1): 21-9.

[61] Huang DB, Mohanty A, DuPont HL, Okhuysen PC, Chiang T. A review of an emerging enteric pathogen: enteroaggregative Escherichia coli. J Med Microbiol 2006; 55(Pt 10): 1303-11.

[62] Nataro JP, Steiner T, Guerrant RL. Enteroaggregative Escherichia coli. Emerg Infect Dis 1998; 4(2): 251-61.

[63] Brooks JT, Ochieng JB, Kumar L, et al. Surveillance for bacterial diarrhea and antimicrobial resistance in rural western Kenya, 19972003. Clin Infect Dis 2006; 43(4): 393-401.

[64] Nataro JP, Mai V, Johnson J, et al. Diarrheagenic Escherichia coli infection in Baltimore, Maryland, and New Haven, Connecticut. Clin Infect Dis 2006; 43(4): 402-7.

[65] Steiner TS, Lima AA, Nataro JP, Guerrant RL. Enteroaggregative Escherichia coli produce intestinal inflammation and growth impairment and cause interleukin-8 release from intestinal epithelial cells. J Infect Dis 1998; 177(1): 88-96.

[66] Nataro JP. Enteroaggregative Escherichia coli pathogenesis. Curr Opin Gastroenterol 2005; 21(1): 4-8.

[67] Fink SL, Cookson BT. Pyroptosis and host cell death responses during Salmonella infection. Cell Microbiol 2007; 9(11): 2562-70.

[68] Kennedy M, Villar R, Vugia DJ, et al. Hospitalizations and deaths due to Salmonella infections, FoodNet, 1996-1999. Clin Infect Dis 2004; 38(Suppl 3): S142-8.

[69] Coburn B, Grassl GA, Finlay BB. Salmonella, the host and disease: a brief review. Immunol Cell Biol 2007; 85(2): 112-8.

[70] McGhie EJ, Brawn LC, Hume PJ, Humphreys D, Koronakis V. Salmonella takes control: effector-driven manipulation of the host Curr Opin Microbiol 2009; 12(1): 117-24

[71] Crump JA, Luby SP, Mintz ED. The global burden of typhoid fever. Bull World Health Organ 2004; 82(5): 346-53.

[72] Parry CM, Hien TT, Dougan G, White NJ, Farrar JJ. Typhoid fever. N Engl J Med 2002; 347(22): 1770-82.

[73] Rudolph JA, Cohen MB. New causes and treatments for infectious diarrhea in children. Curr Gastroenterol Rep 1999; 1(3): 238-44.

[74] Hughes RA, Cornblath DR. Guillain-Barre syndrome. Lancet 2005; 366(9497): 1653-66.

[75] Allos BM. Association between Campylobacter infection and Guillain-Barre syndrome. J Infect Dis 1997; 176(Suppl 2): S125-8.

[76] Camilleri M, Murray JA. Chapter 40. Diarrhea and Constipation. In: Fauci AS BE, Kasper DL, Hauser SL, Longo DL, Jameson JL, Loscalzo J, Eds. Harrison's principles of internal medicine. $17^{\text {th }}$ ed. New York: McGraw-Hill Medical 2008.

[77] Moore SR, Lima AA, Conaway MR, Schorling JB, Soares AM, Guerrant RL. Early childhood diarrhoea and helminthiases associate with long-term linear growth faltering. Int $\mathrm{J}$ Epidemiol 2001; 30(6): 1457-64.

[78] Checkley W, Gilman RH, Black RE, et al. Effect of water and sanitation on childhood health in a poor Peruvian peri-urban community. Lancet 2004; 363(9403): 112-8.

[79] Checkley W, Gilman RH, Epstein LD, et al. Asymptomatic and symptomatic cryptosporidiosis: their acute effect on weight gain in Peruvian children. Am J Epidemiol 1997; 145(2): 156-63.

[80] Checkley W, Epstein LD, Gilman RH, Black RE, Cabrera L, Sterling CR. Effects of Cryptosporidium parvum infection in Peruvian children: growth faltering and subsequent catch-up growth. Am J Epidemiol 1998; 148(5): 497-506.

[81] Guerrant DI, Moore SR, Lima AA, Patrick PD, Schorling JB, Guerrant RL. Association of early childhood diarrhea and cryptosporidiosis with impaired physical fitness and cognitive function four-seven years later in a poor urban community in northeast Brazil. Am J Trop Med Hyg 1999; 61(5): 707-13. 
[82] Lorntz B, Soares AM, Moore SR, et al. Early childhood diarrhea predicts impaired school performance. Pediatr Infect Dis J 2006; 25(6): 513-20

[83] Niehaus MD, Moore SR, Patrick PD, et al. Early childhood diarrhea is associated with diminished cognitive function 4 to 7 years later in children in a northeast Brazilian shantytown. Am J Trop Med Hyg 2002; 66(5): 590-3.

[84] Burgner D, Jamieson SE, Blackwell JM. Genetic susceptibility to infectious diseases: big is beautiful, but will bigger be even better? Lancet Infect Dis 2006; 6(10): 653-63.

[85] Mondal D, Haque R, Sack RB, Kirkpatrick BD, Petri WA, Jr. Attribution of malnutrition to cause-specific diarrheal illness: evidence from a prospective study of preschool children in Mirpur, Dhaka, Bangladesh. Am J Trop Med Hyg 2009; 80(5): 824-6.

[86] Haque R, Mondal D, Shu J, et al. Correlation of interferon-gamma production by peripheral blood mononuclear cells with childhood malnutrition and susceptibility to amebiasis. Am J Trop Med Hyg 2007; 76(2): 340-4.

[87] Ochoa TJ, Salazar-Lindo E, Cleary TG. Management of children with infection-associated persistent diarrhea. Semin Pediatr Infect Dis 2004; 15(4): 229-36.

[88] Bryce J, Boschi-Pinto C, Shibuya K, Black RE. WHO estimates of the causes of death in children. Lancet 2005; 365(9465): 1147-52.

[89] Caulfield LE, de Onis M, Blossner M, Black RE. Undernutrition as an underlying cause of child deaths associated with diarrhea, pneumonia, malaria, and measles. Am J Clin Nutr 2004; 80(1): 193-8.

[90] Cimerman S, Cimerman B, Lewi DS. Prevalence of intestinal parasitic infections in patients with acquired immunodeficiency syndrome in Brazil. Int J Infect Dis 1999; 3(4): 203-6.

[91] Madhivanan $\mathrm{P}$, Mothi SN, Kumarasamy $\mathrm{N}$, et al. Clinical manifestations of HIV infected children. Indian J Pediatr 2003; 70(8): 615-20

[92] Monkemuller KE, Wilcox CM. Gastrointestinal infections in children. Curr Opin Gastroenterol 2001; 17(1): 35-9.

[93] Kownhar H, Shankar EM, Rajan R, Vengatesan A, Rao UA. Prevalence of Campylobacter jejuni and enteric bacterial pathogens among hospitalized HIV infected versus non-HIV infected patients with diarrhoea in southern India. Scand J Infect Dis 2007; 39(10): $862-6$.

[94] Snijders F, Kuijper EJ, de Wever B, van der Hoek L, Danner SA, Dankert J. Prevalence of Campylobacter-associated diarrhea among patients infected with human immunodeficiency virus. Clin Infect Dis 1997; 24(6): 1107-13.

[95] Pozio E, Rezza G, Boschini A, et al. Clinical cryptosporidiosis and human immunodeficiency virus (HIV)-induced immunosuppression: findings from a longitudinal study of HIV-positive and HIV-negative former injection drug users. J Infect Dis 1997; 176(4): 969-75.

[96] Baer JT, Vugia DJ, Reingold AL, Aragon T, Angulo FJ, Bradford WZ. HIV infection as a risk factor for shigellosis. Emerg Infect Dis 1999; 5(6): 820-3.

[97] Amadi B, Kelly P, Mwiya M, et al. Intestinal and systemic infection, HIV, and mortality in Zambian children with persistent diarrhea and malnutrition. J Pediatr Gastroenterol Nutr 2001; 32(5): $550-4$.

[98] Clerinx J, Bogaerts J, Taelman H, et al. Chronic diarrhea among adults in Kigali, Rwanda: association with bacterial enteropathogens, rectocolonic inflammation, and human immunodeficiency virus infection. Clin Infect Dis 1995; 21(5): 1282-4.

[99] Kankwatira AM, Mwafulirwa GA, Gordon MA. Non-typhoidal salmonella bacteraemia--an under-recognized feature of AIDS in African adults. Trop Doct 2004; 34(4): 198-200.

[100] Gordon MA. Salmonella infections in immunocompromised adults. J Infect 2008; 56(6): 413-22.

[101] Angulo FJ, Swerdlow DL. Bacterial enteric infections in persons infected with human immunodeficiency virus. Clin Infect Dis 1995; 21(Suppl 1): S84-93.

[102] UN. The Millennium Development Goals Report. New York: United Nations 2009

[103] Clasen T, Schmidt WP, Rabie T, Roberts I, Cairncross S. Interventions to improve water quality for preventing diarrhoea: systematic review and meta-analysis. BMJ 2007; 334(7597): 782.

[104] Fewtrell L, Colford JM, Jr. Water, sanitation and hygiene in developing countries: interventions and diarrhoea--a review. Water Sci Technol 2005; 52(8): 133-42.
[105] Esrey SA, Potash JB, Roberts L, Shiff C. Effects of improved water supply and sanitation on ascariasis, diarrhoea, dracunculiasis, hookworm infection, schistosomiasis, and trachoma. Bull World Health Organ 1991; 69(5): 609-21.

[106] Cairncross S. More water: better health. People Planet1997; 6(3): $10-1$

[107] Huttly SR, Morris SS, Pisani V. Prevention of diarrhoea in young children in developing countries. Bull World Health Organ 1997; 75(2): 163-74.

[108] Clasen T, Roberts I, Rabie T, Schmidt W, Cairncross S. Interventions to improve water quality for preventing diarrhoea. Cochrane Database Syst Rev 2006; 3: CD004794.

[109] Curtis V, Cairncross S. Effect of washing hands with soap on diarrhoea risk in the community: a systematic review. Lancet Infect Dis 2003; 3(5): $275-81$.

[110] UN. The Millennium Development Goals Report. New York: United Nations 2008.

[111] Echeverria P, Harrison BA, Tirapat C, McFarland A. Flies as a source of enteric pathogens in a rural village in Thailand. Appl Environ Microbiol 1983; 46(1): 32-6.

[112] Cirillo VJ. "Winged sponges": houseflies as carriers of typhoid fever in 19th- and early 20 th-century military camps. Perspect Biol Med 2006; 49(1): 52-63.

[113] Effect of breastfeeding on infant and child mortality due to infectious diseases in less developed countries: a pooled analysis. WHO Collaborative Study Team on the Role of Breastfeeding on the Prevention of Infant Mortality. Lancet 2000; 355(9202): 451-5.

[114] Orlando S. The immunologic significance of breast milk. J Obstet Gynecol Neonatal Nurs 1995; 24(7): 678-83.

[115] Centers for Disease Control and Prevention (CDC). Progress in global measles control and mortality reduction, 2000-2007. MMWR Morb Mortal Wkly Rep 2008; 57(48): 1303-6.

[116] O'Ryan ML, Hermosilla G, Osorio G. Rotavirus vaccines for the developing world. Curr Opin Infect Dis 2009; 22(5): 483-9.

[117] Meeting of the immunization Strategic Advisory Group of Experts, April 2009--conclusions and recommendations. Wkly Epidemiol Rec 2009; 84(23): 220-36.

[118] Calain P, Chaine JP, Johnson E, et al. Can oral cholera vaccination play a role in controlling a cholera outbreak? Vaccine 2004; 22(19): 2444-51.

[119] Lucas ME, Deen JL, von Seidlein L, et al. Effectiveness of mass oral cholera vaccination in Beira, Mozambique. N Engl J Med 2005; 352(8): 757-67.

[120] Chaignat CL. What about cholera vaccines? Expert Rev Vaccines 2008; 7(4): 403-5

[121] Fraser A, Goldberg E, Acosta CJ, Paul M, Leibovici L. Vaccines for preventing typhoid fever. Cochrane Database Syst Rev 2007(3): CD001261.

[122] Phalipon A, Mulard LA, Sansonetti PJ. Vaccination against shigellosis: is it the path that is difficult or is it the difficult that is the path? Microbes Infect 2008; 10(9): 1057-62.

[123] Svennerholm AM, Tobias J. Vaccines against enterotoxigenic Escherichia coli. Expert Rev Vaccines 2008; 7(6): 795-804.

[124] Jagusztyn-Krynicka EK, Laniewski P, Wyszynska A. Update on Campylobacter jejuni vaccine development for preventing human campylobacteriosis. Expert Rev Vaccines 2009; 8(5): 625-45.

[125] Boulter-Bitzer JI, Lee H, Trevors JT. Molecular targets for detection and immunotherapy in Cryptosporidium parvum. Biotechnol Adv 2007; 25(1): 13-44.

[126] McQuaid KR. Gastrointestinal Disorders. In: McPhee S, Papadakis M, Tierney LJ, Eds. Current Medical Diagnosis \& Treatment 2009.

[127] Gross CR, Lindquist RD, Woolley AC, Granieri R, Allard K, Webster B. Clinical indicators of dehydration severity in elderly patients. J Emerg Med 1992; 10(3): 267-74.

[128] Vivanti A, Harvey K, Ash S. Developing a quick and practical screen to improve the identification of poor hydration in geriatric and rehabilitative care. Arch Gerontol Geriatr 2010; 50(2): 156-64.

[129] World Health Organization. Dept. of Child and Adolescent Health and Development. Oral rehydration salts: production of the new ORS. Geneva: World Health Organ 2006.

[130] World Health Organization. Dept. of Child and Adolescent Health and Development., UNICEF. Clinical management of acute diarrhea. WHO/UNICEF joint statement. Geneva: World Health Organ 2004. 
[131] Sazawal S, Black RE, Bhan MK, Bhandari N, Sinha A, Jalla S. Zinc supplementation in young children with acute diarrhea in India. N Engl J Med 1995; 333(13): 839-44.

[132] Roy SK, Tomkins AM, Akramuzzaman SM, et al. Randomised controlled trial of zinc supplementation in malnourished Bangladeshi children with acute diarrhoea. Arch Dis Child 1997; 77(3): 196-200.

[133] Lazzerini M, Ronfani L. Oral zinc for treating diarrhoea in children. Cochrane Database Syst Rev 2008; (3): CD005436.

[134] Bhutta ZA, Black RE, Brown KH, et al. Prevention of diarrhea and pneumonia by zinc supplementation in children in developing countries: pooled analysis of randomized controlled trials. Zinc Investigators' Collaborative Group. J Pediatr 1999; 135(6): 689-97.

[135] Bhutta ZA, Bird SM, Black RE, et al. Therapeutic effects of oral zinc in acute and persistent diarrhea in children in developing countries: pooled analysis of randomized controlled trials. Am J Clin Nutr 2000; 72(6): 1516-22.

[136] Brooks WA, Santosham M, Naheed A, et al. Effect of weekly zinc supplements on incidence of pneumonia and diarrhoea in children younger than 2 years in an urban, low-income population in Bangladesh: randomised controlled trial. Lancet 2005; 366(9490): 999-1004.

[137] Baqui AH, Black RE, El Arifeen S, et al. Effect of zinc supplementation started during diarrhoea on morbidity and mortality in Bangladeshi children: community randomised trial. BMJ 2002; 325(7372): 1059.

[138] Fontaine O. Effect of zinc supplementation on clinical course of acute diarrhoea. J Health Popul Nutr 2001; 19(4): 339-46.

[139] Brown KH, Rivera JA, Bhutta Z, et al. International Zinc Nutrition Consultative Group (IZiNCG) technical document \#1. Assessment of the risk of zinc deficiency in populations and options for its control. Food Nutr Bull 2004; 25(1 Suppl 2): S99-203.

[140] Ghishan FK. Transport of electrolytes, water, and glucose in zinc deficiency. J Pediatr Gastroenterol Nutr 1984; 3(4): 608-12.

[141] Bettger WJ, O'Dell BL. A critical physiological role of zinc in the structure and function of biomembranes. Life Sci 1981; 28(13): 1425-38.

[142] Gebhard RL, Karouani R, Prigge WF, McClain CJ. The effect of severe zinc deficiency on activity of intestinal disaccharidases and 3-hydroxy-3-methylglutaryl coenzyme A reductase in the rat. J Nutr 1983; 113(4): 855-9.

[143] Roy SK, Behrens RH, Haider R, et al. Impact of zinc supplementation on intestinal permeability in Bangladeshi children with acute diarrhoea and persistent diarrhoea syndrome. J Pediatr Gastroenterol Nutr 1992; 15(3): 289-96.

[144] Shankar AH, Prasad AS. Zinc and immune function: the biological basis of altered resistance to infection. Am J Clin Nutr 1998; 68(2 Suppl): 447S-63S

[145] Taylor CE, Greenough WB, 3rd. Control of diarrheal diseases. Annu Rev Public Health 1989; 10: 221-44.

[146] Richards L, Claeson M, Pierce NF. Management of acute diarrhea in children: lessons learned. Pediatr Infect Dis J 1993; 12(1): 5-9.

[147] Bhattacharya SK, Sur D. An evaluation of current shigellosis treatment. Expert Opin Pharmacother 2003; 4(8): 1315-20.

[148] Dutta S, Dutta D, Dutta P, Matsushita S, Bhattacharya SK, Yoshida S. Shigella dysenteriae serotype 1, Kolkata, India. Emerg Infect Dis 2003; 9(11): 1471-4.

[149] MoezArdalan K, Zali MR, Dallal MM, Hemami MR, Salmanzadeh-Ahrabi S. Prevalence and pattern of antimicrobial resistance of Shigella species among patients with acute diarrhoea in Karaj, Tehran, Iran. J Health Popul Nutr 2003; 21(2): 96-102.

[150] von Seidlein L, Kim DR, Ali M, et al. A multicentre study of Shigella diarrhoea in six Asian countries: disease burden, clinical manifestations, and microbiology. PLoS Med 2006; 3(9): e353.

[151] Pazhani GP, Sarkar B, Ramamurthy T, Bhattacharya SK, Takeda Y, Niyogi SK. Clonal multidrug-resistant Shigella dysenteriae type 1 strains associated with epidemic and sporadic dysenteries in eastern India. Antimicrob Agents Chemother 2004; 48(2): 681-4

[152] Kuo CY, Su LH, Perera J, et al. Antimicrobial susceptibility of Shigella isolates in eight Asian countries, 2001-2004. J Microbiol Immunol Infect 2008; 41(2): 107-11.
[153] World Health Organization. Department of Immunization Vaccines and Biologicals., World Health Organization. Department of Communicable Disease Prevention Control and Eradication., World Health Organization. Department of Child and Adolescent Health and Development. Guidelines for the control of shigellosis, including epidemics due to Shigella dysenteriae type 1. Geneva: World Health Organ 2005.

[154] Dundas S, Todd WT, Stewart AI, Murdoch PS, Chaudhuri AK, Hutchinson SJ. The central Scotland Escherichia coli O157: H7 outbreak: risk factors for the hemolytic uremic syndrome and death among hospitalized patients. Clin Infect Dis 2001; 33(7): 923-31

[155] Bavaro MF. Escherichia coli O157: what every internist and gastroenterologist should know. Curr Gastroenterol Rep 2009; 11(4): 301-6.

[156] Kimmitt PT, Harwood CR, Barer MR. Toxin gene expression by shiga toxin-producing Escherichia coli: the role of antibiotics and the bacterial SOS response. Emerg Infect Dis 2000; 6(5): 458-65.

[157] Bhattacharya SK. An evaluation of current cholera treatment. Expert Opin Pharmacother 2003; 4(2): 141-6.

[158] Lawler JV, Wallace MR. Diagnosis and treatment of bacterial diarrhea. Curr Gastroenterol Rep 2003; 5(4): 287-94.

[159] Phavichitr N, Catto-Smith A. Acute gastroenteritis in children: what role for antibacterials? Paediatr Drugs 2003; 5(5): 279-90.

[160] Guerrant RL, Van Gilder T, Steiner TS, et al. Practice guidelines for the management of infectious diarrhea. Clin Infect Dis 2001; 32(3): 331-51.

[161] Bhutta ZA, Ghishan F, Lindley K, Memon IA, Mittal S, Rhoads JM. Persistent and chronic diarrhea and malabsorption: Working Group report of the second World Congress of Pediatric Gastroenterology, Hepatology, and Nutrition. J Pediatr Gastroenterol Nutr 2004; 39(Suppl 2): S711-6.

[162] Lebenthal E. Chronic diarrhea in children. New York: Raven Press; 1984

[163] Lunn PG, Northrop-Clewes CA, Downes RM. Recent developments in the nutritional management of diarrhoea. 2 Chronic diarrhoea and malnutrition in The Gambia: studies on intestinal permeability. Trans R Soc Trop Med Hyg 1991; 85(1): 811.

[164] Sullivan PB. Studies of the small intestine in persistent diarrhea and malnutrition: the Gambian experience. J Pediatr Gastroenterol Nutr 2002; 34(Suppl 1): S11-3.

[165] Black RE. Persistent diarrhea in children of developing countries Pediatr Infect Dis J 1993; 12(9): 751-61; discussion 762-4.

[166] Abba K, Sinfield R, Hart CA, Garner P. Antimicrobial drugs for persistent diarrhoea of unknown or non-specific cause in children under six in low and middle income countries: systematic review of randomized controlled trials. BMC Infect Dis 2009; 9: 24.

[167] Beck DL, Dogan N, Maro V, Sam NE, Shao J, Houpt ER. High prevalence of Entamoeba moshkovskii in a Tanzanian HIV population. Acta Trop 2008; 107(1): 48-9.

[168] Gatei W, Wamae CN, Mbae C, et al. Cryptosporidiosis: prevalence, genotype analysis, and symptoms associated with infections in children in Kenya. Am J Trop Med Hyg 2006; 75(1): 78-82.

[169] Moyo SJ, Gro N, Kirsti V, et al. Prevalence of enteropathogenic viruses and molecular characterization of group A rotavirus among children with diarrhea in Dar es Salaam Tanzania. BMC Public Health 2007; 7: 359

[170] Kiulia NM, Peenze I, Dewar J, et al. Molecular characterisation of the rotavirus strains prevalent in Maua, Meru North, Kenya. East Afr Med J 2006; 83(7): 360-5

[171] Venkataraman S, Ramakrishna BS, Kang G, Rajan DP, Mathan VI. Faecal lactoferrin as a predictor of positive faecal culture in south Indian children with acute diarrhoea. Ann Trop Paediatr 2003; 23(1): 9-13.

[172] Ma T, Thiagarajah JR, Yang $\mathrm{H}$, et al. Thiazolidinone CFTR inhibitor identified by high-throughput screening blocks cholera toxin-induced intestinal fluid secretion. J Clin Invest 2002; 110(11): 1651-8 
[173] Hoque KM, Rajendran VM, Binder HJ. Zinc inhibits cAMPstimulated $\mathrm{Cl}$ secretion via basolateral $\mathrm{K}$-channel blockade in rat ileum. Am J Physiol Gastrointest Liver Physiol 2005; 288(5): G956-63.

[174] Ramakrishna BS, Subramanian V, Mohan V, et al. A randomized controlled trial of glucose versus amylase resistant starch hypo- osmolar oral rehydration solution for adult acute dehydrating diarrhea. PLoS One 2008; 3(2): e1587.

[175] Raghupathy P, Ramakrishna BS, Oommen SP, et al. Amylaseresistant starch as adjunct to oral rehydration therapy in children with diarrhea. J Pediatr Gastroenterol Nutr 2006; 42(4): 362-8.

(c) Ahs et al.; Licensee Bentham Open.

This is an open access article licensed under the terms of the Creative Commons Attribution Non-Commercial License (http://creativecommons.org/licenses/ by-nc/3.0/) which permits unrestricted, non-commercial use, distribution and reproduction in any medium, provided the work is properly cited. 